\title{
Managing soybean rust with fungicides and varieties of the early/semi-early and intermediate maturity groups
}

\author{
Lucimara J. Koga ${ }^{1}$, Marcelo G. Canteri' ${ }^{1}$, Eberson S. Calvo ${ }^{2}$, Daiane C. Martins ${ }^{1}$, Sheila Ariana Xavier ${ }^{1}$, Arlindo \\ Harada $^{2}$ \& Romeu A. S. Kiihl ${ }^{2}$ \\ ${ }^{1}$ Departamento de Agronomia, Universidade Estadual de Londrina, Cx. Postal 6001, 86051-970, Londrina, PR, Brazil; \\ ${ }^{2}$ Tropical Melhoramento \& Genética LTDA, Cx. Postal 387, 86183-600, Cambé, PR, Brazil
}

Author for correspondence: Marcelo G. Canteri, e-mail: canteri@uel.br

\begin{abstract}
The objectives of this study were to evaluate the influence of soybean cultivar of two maturity groups, early/semi-early (E) or intermediate (I), on the management of Asian soybean rust (ASR) with fungicides and yield. Field trials were conducted during the 2006/07 and 2007/08 growing seasons. Seven cultivars of the two groups were tested in the first season and eight in the second season. All cultivars had plots that were treated (T) or non-treated (NT) with a commercial mixture of pyraclostrobin + epoxiconazole. ASR severity (\%) was visually assessed several times during the crop cycle and yield $\left(\mathrm{kg} \mathrm{ha}^{-1}\right)$ was determined at harvest. Values of the standardized area under the disease progress curve (AUDPC) calculated from the severity assessments was higher in 2007/08 than in 2006/07, but no differences were found between cultivars of the E and I maturity groups. Differences in yield between between T and NT plots were lower in cultivars of the E group than those of the I group in both the 2006/07 (37.6\% and 52.8\% respectively) and the 2007/08 season (56.9\% and $85.0 \%$, respectively). A higher stability in yield was found for cultivars of the E maturity group compared to those of the I group.
\end{abstract}

Key words: Glycine max, Phakopsora pachyrhizi, fungicide efficacy.

\section{INTRODUCTION}

Asian soybean rust (ASR), caused by Phakopsora pachyrhizi Syd. \& P. Syd., is among the most important diseases that threaten soybean [Glycine $\max$ (L.) Merrill] production worldwide (Arias, 2004; Embrapa Soja, 2008). In South America, ASR was first reported in Brazil during the 2000/01 season (Yorinori et al., 2005), furthering spread into other regions of the continent. However, major economic impact of the disease has been reported in Brazil, Paraguay and Bolivia, where climatic conditions are often favorable for ASR epidemics (Yorinori et al., 2005).

Climatic factors play a key role in ASR epidemics. Continuous leaf wetness due to dew or rainfall under the optimal range of temperature $\left(18\right.$ to $26.5^{\circ} \mathrm{C}$ ) favors disease development (Melching et al., 1989; Alves et al., 2006). In field epidemics, rainfall plays a major role in disease development (Del Ponte et al., 2006).

The recommended practices to manage the disease include avoiding inter-seasonal cropping and applying fungicides preventatively or as soon as the disease is detected in the field. Also, earliness of sowing time, whenever possible, and use of cultivars of the early maturity group are recommended practices based on the avoidance principle

Part of the Ph.D. Thesis of the first author. Universidade Estadual de Londrina. Londrina PR. 2008.
(Arahana et al., 2001; Bergamin Filho et al., 1995). The objective of this study was to evaluate the combined effect of soybean cultivars of the early and intermediate maturity groups and a standard fungicide treatment on disease development, control efficacy and soybean yield.

\section{MATERIAL AND METHODS}

A two-year experiment was conducted at the research center of Melhoramento \& Genética Ltda. (TMG), located

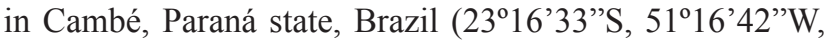
elevation $650 \mathrm{~m}$ ). The soil was classified as a dark red eutrophic oxisol (Brazilian classification: Latossolo Roxo Eutrófico). The first trial was sown on 02/12/2006 and the second on $05 / 12 / 2007$, respectively. Seeds were treated with a commercial product based on a mixture of carbendazim and thiram (200 mL c.p. 100/kg seeds). As to fertilizers, 300 $\mathrm{kg} / \mathrm{ha}$ of NPK 0-20-20 was applied. Insect pests and weeds were controlled as needed.

The experiments were set in a complete randomized block design with three replications (plots). Each plot consisted of four $5-\mathrm{m}$ rows spaced at $0.5 \mathrm{~m}$. Data were collected in the two middle rows. Seven and eight cultivars were tested in the first year and second year, respectively, and they represented three maturity groups (Table 1). In both trials, plots were either non-treated (NT, or a check treatment) or treated $(\mathrm{T})$ with a commercial mixture of pyraclostrobin + epoxiconazole (66.5 g plus $25 \mathrm{~g}$ i.a./ha, 
respectively). In both years, $\mathrm{T}$ plots were sprayed five times at a 15-day interval. The first spray was made 44 and 41 days after sowing (DAS) in 2006/06 and 2007/08 season, respectively. Fungicides were applied using a $\mathrm{CO}_{2}$ backpack sprayer (Teejet XR 11002) with a $2 \mathrm{~m}$ spray boom and four nozzles spaced at $0.5 \mathrm{~m}$. The volume of fungicide was equivalent to $300 \mathrm{~L} / \mathrm{ha}$.

ASR epidemics developed naturally in the trials. Disease severity was evaluated weekly after disease detection. Percent diseased area was estimated with the aid of diagrammatic scale (Godoy et al., 2006) in a sample of leaves taken from the lower, middle and upper canopy height at four randomly selected points in the plots. The severity data estimated over time were used to calculate the area under the disease progress curve (AUDPC) (Campbell \& Madden, 1990), which was standardized (divided by epidemic duration in days) (Fry, 1977) to compare cultivars of different maturity groups.

The number of days required to reach maturity stage (R9) was estimated with the aid of a modified (Yorinori, 1996) scale that describes soybean phenology (Ritchie et al., 1982). The developmental stage of each plot was recorded during each severity assessments. Plots were harvested and threshed mechanically and thousand grain weight and moisture content were determined for each plot. Yield was calculated in $\mathrm{kg} / \mathrm{ha}$ and corrected for $13 \%$ moisture content.

The two experiments were analyzed independently. AUDPCs and yield data were subjected to analysis of variance and the means compared using Scott-Knott's test (Silva et al., 1999). Attainable yield was determined based on the difference in yield between T and NT plots and significance of the difference was assessed using a Tukey's test. Statistical analyses were carried out using SASM-Agri software (Canteri et al., 2001).

\section{RESULTS AND DISCUSSION}

First symptoms of ASR $(<0.1 \%$ severity) were found in both seasons at around $60 \mathrm{DAS}$, or between $\mathrm{Vn}$ to R2 stages depending on the variety. Mean AUDPC was higher in 2007/08 than in 2006/07 in the NT plots (Table 2), possibly due to differences in the meteorological conditions between seasons (Figure 1). The mean temperature during specific stages of crop development, in both years, was within the favorable range $\left(18\right.$ to $\left.26.5^{\circ} \mathrm{C}\right)$ for the development ASR epidemics (Alves et al., 2006; Melching et al., 1989; Yorinori et al., 2004). However, 2006/07 was in general warmer than 2007/08 during the crop cycle (Figure 1A).

The availability of water is critical for soybean development, especially from sowing to emergence (S-Emerg) and from flowering to grain filling (R2-R6), periods that require on average 7 to 8 mm.day-1 (Embrapa Soja, 2008). In both years, early-season rainfall was sufficient to support crop development and favor the onset of ASR epidemics. In 2006/07 season, for example, cumulative rainfall $(888.2 \mathrm{~mm})$ was above the threshold that maximizes soybean yield (480 to $800 \mathrm{~mm}$ ) (Embrapa Soja, 2008). In 2007/08, although cumulative rainfall was in that optimal range $(716 \mathrm{~mm})$, rainfall events were unevenly distributed with periods of severe drought $(<1 \mathrm{~mm} /$ day $)$ recorded from R2 to R4 stages (Figure 1B).

In polycyclic epidemics caused by Phakopsora pachyrhizi, differently from other diseases, lesion growth is the result of increasing numbers of uredinia over the already existing lesions for as long as six weeks (Melching, 1979; Bergamin Filho, 2006). Hence, the disease is able to continue development due the high number of latent infections even under less favorable wetness conditions for new infections. Moreover, since older lesions are capable of reallocating energy for uredinia formation, a large reservoir of inoculum will be available to disperse and infect the plant in the next rainfall event. These may partially explain the higher mean final severity found in the second season (Table 2), although the dry periods in the mid-season (Figure 1B). Mean severity in the NT plots of all varieties increased considerably (6\% to $31 \%$ ) between 78 and 85 DAS in $2007 / 08$ and only modestly (5.2\% to $8.3 \%$ ) between 82 and 89 DAS in 2006/07 (data not shown).

Cultivars of the early and intermediate maturity groups were not discriminated by the AUDPC values (Table 2). Literature data shows that ASR epidemic rates are influenced by the stage of the soybean crop (Tschanz \& Wang, 1985; Hartman et al., 1991). Hence, early maturing genotypes are as susceptible as late maturing ones when compared at the same stage of development and under similar inoculum pressure and environmental conditions. Although the differences in days to mature among the cultivars tested in this study, the disease developed similarly. This may be related to the high demand for photoassimilates and nutrients during reproductive stages, not impairing its capability to limit disease progress (Yujun, 1991; Andrade \& Andrade, 2010).

ASR control averaged around 46\% in 2006/07 and $80 \%$ in $2007 / 08$. Such differences in control efficacy may also relate to environmental differences between seasons. Although drier, the second season had lower temperature compared to the first season. These conditions in 2007/08 may have prevented loss of fungicide due to rainfall or evaporation, thus leading to a better control compared to the previous seasons when AUDPC values did not differ between NT of some varieties and $\mathrm{T}$ of other varieties (Table 2).

The rationale for using early-maturity varieties for managing ASR is to decrease the time period for epidemic development, thus preventing yield loss by the disease. In both years, differences in yield between $\mathrm{T}$ and NT plots for early/semi-early maturity cultivars were lower $(37.57 \%$ and $56.9 \%$ ) than those of intermediate maturity cultivars $(52.77 \%$ and $84.9 \%)$. The three semi-early cultivars also showed attainable yield equal or higher than intermediate cycle cultivars in both seasons (Table 3). Since genotype 

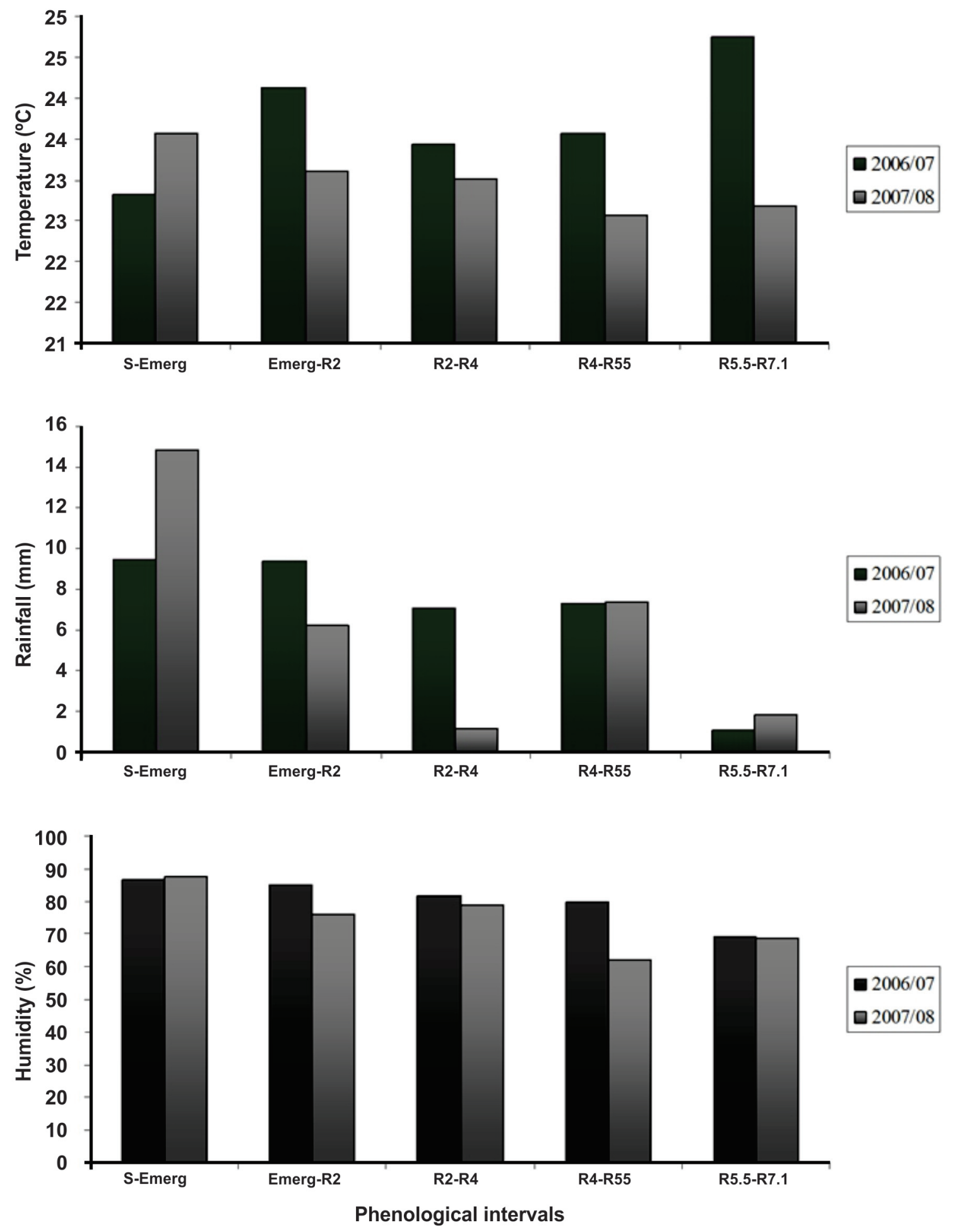

FIGURE 1 - Mean values of temperature $\left({ }^{\circ} \mathrm{C}\right)$, rainfall $(\mathrm{mm})$ and relative humidity $(\%)$ during specific soybean developmental stages: sowing-emergence (S-Emerg), emergence-full bloom (Emerg-R2), full bloom-pods 2-4 cm (R2-R4), pods 2-4 cm-pods 75-100\% filled (R4-R5.5), pods 75-100\% filled-up to 50\% leaf and pod yellowing (R5.5-R7.1), during the 2006/07 and 2007/08 cropping seasons.

sensitivity to environment plays a major role in crop performance (Rocha \& Vello, 1999), the semi-early yielded better than other cultivars in this study. Knowledge on the performance of the different maturity groups under conditions favorable for ASR epidemic and fungicide control is important for planning decisions of which variety to use and when to plant, with the aim to maximize yield and profits. 
TABLE 1 - Main characteristics of the soybean cultivars evaluated during the 2006/07 and 2007/08 cropping seasons.

\begin{tabular}{|c|c|c|}
\hline Cultivar & Maturity group ${ }^{a}$ & $\begin{array}{l}\text { Regions of adaptation } \\
\text { (Brazilian states) }\end{array}$ \\
\hline BRS 133 & Intermediate & Santa Catarina, São Paulo, Paraná and Mato Grosso do Sul \\
\hline Msoy 8001 & Intermediate & South, São Paulo, Mato Grosso do Sul, Minas Gerais and Goiás \\
\hline BRS 231 & Intermediate & Santa Catarina, São Paulo and Paraná \\
\hline BRS 258 & Intermediate & Santa Catarina, São Paulo and Paraná \\
\hline BR 36 & Semi-early & Santa Catarina and Paraná \\
\hline BRS 232 & Semi-early & Santa Catarina, São Paulo and Paraná \\
\hline BRS 257 & Semi-early & Santa Catarina, São Paulo and Paraná \\
\hline CD 214RR & Early & $\begin{array}{l}\text { Santa Catarina, São Paulo, Paraná, Rio Grande do Sul and } \\
\text { Mato Grosso do Sul }\end{array}$ \\
\hline
\end{tabular}

a'Maturity group: early (up to 115 days after emergence - DAE); semi-early (116 to 125 DAE); intermediate (126 to 137 DAE).

TABLE 2 - Standardized area under disease progress curve (AUDPC) for soybean cultivars of different maturity groups in plots untreated (NT) and treated (T) with piraclostrobin plus epoxiconazole in the 2006/07 and 2007/08 cropping seasons.

\begin{tabular}{|c|c|c|c|c|c|c|c|c|c|}
\hline \multirow[b]{2}{*}{ Cultivar } & \multirow[b]{2}{*}{ Cycle $^{a}$} & \multicolumn{4}{|c|}{$2006 / 07$} & \multicolumn{3}{|c|}{$2007 / 08$} & \\
\hline & & NT & & $\mathbf{T}$ & & NT & & $\mathbf{T}$ & \\
\hline BRS 133 & Intermediate & 31.70 & $a^{*}$ & 23.12 & $\mathrm{~b}$ & 44.48 & $\mathrm{a}$ & 11.91 & $\mathrm{c}$ \\
\hline Msoy 8001 & Intermediate & 31.86 & $\mathrm{a}$ & 18.07 & $\mathrm{~b}$ & 50.59 & $\mathrm{a}$ & 13.82 & $\mathrm{c}$ \\
\hline BRS 231 & Intermediate & 32.72 & $\mathrm{a}$ & 20.54 & $\mathrm{~b}$ & 45.68 & $\mathrm{a}$ & 10.80 & $\mathrm{c}$ \\
\hline BRS 258 & Intermediate & 24.92 & $\mathrm{~b}$ & 10.16 & $\mathrm{c}$ & 44.67 & $\mathrm{a}$ & 6.55 & $\mathrm{c}$ \\
\hline BR 36 & Semi & 31.62 & $\mathrm{a}$ & 16.95 & $\mathrm{~b}$ & 34.65 & $\mathrm{~b}$ & 3.43 & d \\
\hline BRS 232 & Semi & 23.34 & $\mathrm{~b}$ & 9.30 & $\mathrm{c}$ & 44.31 & $\mathrm{a}$ & 7.66 & $\mathrm{c}$ \\
\hline BRS 257 & Semi & - & - & - & - & 38.37 & $\mathrm{~b}$ & 8.31 & $\mathrm{c}$ \\
\hline CD 214RR & Early & 25.34 & $\mathrm{~b}$ & 10.17 & $\mathrm{c}$ & 46.55 & $\mathrm{a}$ & 9.14 & $\mathrm{c}$ \\
\hline Mean & - & 28.78 & - & 15.47 & - & 43.66 & - & 8.95 & - \\
\hline C.V. $(\%)$ & - & & 7.91 & & & & 15.02 & & \\
\hline
\end{tabular}

${ }^{a}$ Maturity group: early (up to 115 days after emergence - DAE); semi-early (116 to 125 DAE); intermediate (126 to 137 DAE)

*Means followed by the same letter did not differ in the Scott-Knott test at $1 \%$ probability.

TABLE 3 - Yield $\left(\mathrm{kg} \mathrm{ha}^{-1}\right)$ in plots untreated (NT) and treated (T) with pyraclostrobin plus epoxiconazole, respective differences and percentage differences during the 2006/07 and 2007/08 cropping seasons for soybean cultivars of different maturity groups.

\begin{tabular}{|c|c|c|c|c|c|c|c|c|c|}
\hline \multirow[b]{2}{*}{ Cultivar } & \multirow[b]{2}{*}{ Treat. } & \multicolumn{4}{|c|}{$2006 / 07$} & \multicolumn{4}{|c|}{$2007 / 08$} \\
\hline & & $\mathrm{kg} \mathrm{ha}^{-1}$ & & $\begin{array}{c}\text { Difference } \\
\mathrm{T}-\mathrm{NT}^{\mathrm{a}}\end{array}$ & $\begin{array}{c}\% \\
\text { difference }\end{array}$ & $\mathrm{kg} \mathrm{ha}^{-1}$ & & $\begin{array}{c}\text { Difference } \\
\text { T - NT }\end{array}$ & $\begin{array}{c}\% \\
\text { difference }\end{array}$ \\
\hline \multirow[t]{2}{*}{ BRS 133} & NT & 1231.21 & $\mathrm{~d}^{*}$ & $1787.35^{* *}$ & 59.21 & 428.94 & $\mathrm{~g}$ & $2750.14 * *$ & 86.51 \\
\hline & $\mathrm{T}$ & 3018.56 & $\mathrm{~b}$ & - & - & 3179.08 & $\mathrm{~b}$ & - & - \\
\hline \multirow[t]{2}{*}{ Msoy 8001} & NT & 1190.92 & d & $1431.68^{*}$ & 54.59 & 207.90 & g & $2467.57 * *$ & 92.23 \\
\hline & $\mathrm{T}$ & 2622.60 & $\mathrm{c}$ & - & - & 2675.47 & $\mathrm{c}$ & - & - \\
\hline \multirow[t]{2}{*}{ BRS 231} & NT & 1190.47 & d & $1158.52 *$ & 49.32 & 408.28 & g & $2665.74 * *$ & 86.72 \\
\hline & $\mathrm{T}$ & 2348.99 & $\mathrm{c}$ & - & - & 3074.02 & $\mathrm{~b}$ & - & - \\
\hline \multirow[t]{2}{*}{ BRS 258} & NT & 1994.38 & $\mathrm{c}$ & $1838.97^{*}$ & 47.97 & 870.17 & $\mathrm{f}$ & $2530.24 * *$ & 74.41 \\
\hline & $\mathrm{T}$ & 3833.35 & $\mathrm{a}$ & - & - & 3400.41 & b & - & - \\
\hline \multirow[t]{2}{*}{ BR 36} & NT & 2547.14 & $\mathrm{c}$ & $1689.30 *$ & 39.88 & 1774.49 & d & $2174.00 * *$ & 55.06 \\
\hline & $\mathrm{T}$ & 4236.44 & $\mathrm{a}$ & - & - & 3948.49 & $\mathrm{a}$ & - & - \\
\hline \multirow[t]{2}{*}{ BRS 232} & NT & 2185.48 & $\mathrm{c}$ & $1265.48^{*}$ & 36.67 & 1338.18 & $\mathrm{e}$ & $2584.27 * *$ & 65.88 \\
\hline & $\mathrm{T}$ & 3450.96 & $\mathrm{~b}$ & - & - & 3922.45 & $\mathrm{a}$ & - & - \\
\hline \multirow[t]{2}{*}{ BRS 257} & NT & - & - & - & - & 1651.27 & d & $1740.87 * *$ & 51.32 \\
\hline & $\mathrm{T}$ & - & - & - & - & 3392.14 & b & - & - \\
\hline \multirow[t]{2}{*}{ CD 214RR } & NT & 1662.22 & d & $941.75 *$ & 36.17 & 1285.01 & $\mathrm{e}$ & $1605.60^{*}$ & 55.55 \\
\hline & $\mathrm{T}$ & 2603.97 & $\mathrm{c}$ & & & 2890.61 & $\mathrm{c}$ & - & - \\
\hline C.V. $(\%)$ & & 15.93 & & & & 8.71 & & & \\
\hline
\end{tabular}

\footnotetext{
* Means followed by the same letter did not differ in the Scott-Knott test at $1 \%$ probability.
}

a*, significant at $5 \%$; **, significant at $1 \%$ in Tukey's test. 


\section{ACKNOWLEDGEMENTS}

To Conselho Nacional de Desenvolvimento Científico e Tecnológico - CNPq for a scholarship awarded to the first author.

\section{REFERENCES}

Alves SAM, Furtado GQ, Bergamin Filho A (2006) Influência das condições climáticas sobre a ferrugem da soja. In: Zambolim L (Ed.) Ferrugem asiática da soja. Viçosa, MG. Suprema Gráfica e Editora Ltda. pp. 37-59.

Andrade PJA, Andrade FAA (2010) O que está acontecendo com a ferrugem da soja em Mato Grosso do Sul? - Repensando o manejo da doença. Available at: http://www.cpao.embrapa.br/ publicacoes/ferrugem/release_Paulino_CLP_Artigo-Ferrugem-v. html. Accessed on June 21, 2010.

Arahana VS, Graef GK, Specht JE, Steadman JR, Eskridge KM (2001) Identification of QTLs for resistance to Sclerotinia sclerotiorum in soybean. Crop Science 41:180-188.

Arias CAA, Ribeiro AS, Yorinori JT, Brogin RL, Oliveira MF, Toledo JFF (2004) Inheritance of resistance of soybean to rust (Phakospora pachyrhizi Sidow). In: VII World Soybean Research Conference, Proceedings... Foz do Iguaçu, PR. Embrapa Soja. p. 100 .

Azevedo LAS (2007) Fungicidas sistêmicos: Teoria e Prática. 1. ed. Campinas, SP. EMOPI.

Bergamin Filho A, Kimati H, Amorim L (1995) Manual de Fitopatologia. 3rd Ed. São Paulo, SP. Editora Agronômica Ceres.

Bergamin Filho A (2006) Epidemiologia comparativa: Ferrugem da soja e outras doenças. In: Zambolim L (Ed.) Ferrugem Asiática da Soja. Viçosa, MG. Editora UFV. pp.15-35.

Campbell CL, Madden L (1990) Introduction to Plant Disease Epidemiology. New York, NY, USA. Wiley.

Canteri MG, Althaus RA, Virgens Filho JS, Giglioti EA, Godoy CV (2001) SASM - Agri: Sistema para análise e separação de médias em experimentos agrícolas pelos métodos Scott-Knott, Tukey e Duncan. Revista Brasileira de Agrocomputação 1:18-24.

Del Ponte EM, Godoy CV, Li X, Yang XB (2006) Predicting severity of Asian soybean rust epidemics with empirical rainfall models. Phytopathology 96:797-803.
Embrapa Soja (2008) Tecnologias de produção de soja: Região Central do Brasil 2008. Londrina, PR. Embrapa Soja.

Fry WE (1977) Integrated control of potato late blight - Effects of polygenic resistance and techniques of timing fungicide applications. Phytopathology 68:1650-1655.

Godoy CV, Koga LJ, Canteri MG (2006) Diagrammatic scale for assessment of soybean rust severity. Fitopatologia Brasileira 31:63-68.

Hartman GL, Wang TC, Tschanz AT (1991) Soybean rust development and quantitative relationship between rust severity and soybean yield. Plant Disease 75:596-600.

Melching JS, Bromfield KR, Kingsolver CH (1979) Infection, colonization, and uredospore production on Wayne soybean by four cultures of Phakopsora pachyrhizi, the cause of soybean rust. Phytopathology 69:1262-1265.

Melching JS, Dowler WM, Koogle DL, Royer MH (1989) Effect of duration, frequency, and temperature of leaf wetness period on soybean rust. Plant Disease 73:117-122.

Ritchie S, Hanway JJ, Thompson HE (1982) How a soybean plant develops. Ames, IA, USA. Iowa State University.

Rocha MM, Vello NA (1999) Interação genótipos e locais para rendimento de grãos de linhagens de soja com diferentes ciclos de maturação. Bragantia 58:69-81.

Silva EC, Ferreira DF, Bearzoti E (1999) Avaliação do poder e taxas de erro tipo I do teste de Scott-Knott por meio de método de Monte Carlo. Ciência Agrotécnica 23:687-696.

Tschanz AT, Wang TC (1985) Interrelationship between soybean development, resistance, and Phakopsora pachyrhizi. Phytopathology 81:1420-1426.

Yorinori JT (1996) Doenças da soja no Brasil. In: Fundação Cargill. Soja no Brasil Central. Campinas, SP. Fundação Cargill. pp. 301-363.

Yorinori JT, Lazzarotto JJ (2004) Situação da ferrugem asiática da soja no Brasil e na América do Sul. Londrina, PR. Embrapa Soja.

Yorinori JT, Paiva WM, Frederick RD, Costamilan LM, Bertagnolli PF, Hartman GE, Godoy CV, Nunes Junior J (2005) Epidemics of soybean rust (Phakopsora pachyrhizi) in Brazil and Paraguay. Plant Disease 89:675-677.

Yujun T (1991) Epidemiology of soybean rust in China. Phytopathology 81:1420-1426. 